\title{
Repeated measurement of habitual food intake increases under-reporting and induces selective under-reporting
}

\author{
Annelies H. C. Goris*, Erwin P. Meijer and Klaas R. Westerterp \\ Department of Human Biology, Maastricht University, The Netherlands
}

(Received 23 June 2000 - Revised 25 October 2000 - Accepted 13 December 2000)

\begin{abstract}
The aim of the current study was to measure differences in reporting behaviour between a first occasion of $7 \mathrm{~d}$ food recording and a second occasion of $7 \mathrm{~d}$ food recording 12 weeks later, in a group of elderly men $(n 17)$ and women $(n 17)$. Half the group followed an exercise intervention. The mean age was 61 (SD 5) years and mean BMI was $26 \cdot 2$ (SD $3 \cdot 8$ ) $\mathrm{kg} / \mathrm{m}^{2}$. Reported energy intake was compared with energy expenditure as calculated from measured BMR and physical activity assessed with a tri-axial accelerometer for movement registration. Total under-reporting was divided into undereating and under-recording. Undereating was calculated from the change in body mass over the recording week and the under-recording was measured using the water balance technique. In the first period, the total under-reporting was $21 \%$ and increased to $27 \%$ in the second period $(P=0.03)$. In the first period there was no indication for subjects eating less during the recording week, however, in the second period subjects lost body mass during the food recording indicating undereating. The amount of under-recording was calculated at $21 \%$ in the first period and $18 \%$ in the second period of recording $(P 0 \cdot 28)$. During the second period subjects selectively under-reported their fat intake and over-reported their protein intake. In conclusion, repeated assessment of food intake caused a higher quantitative and a qualitative under-reporting of food intake. The effect of interventions (dietary or otherwise) on habitual food intake might be confounded by changes in food-reporting behaviour.
\end{abstract}

Repeated dietary assessment: Energy balance: Selective under-reporting

In intervention studies on diet components or behaviour, effects on food intake are often studied. However, the aimed effects of the intervention on the food intake are probably not only due to the intervention, but also due to changes in food intake reporting. It is known that underreporting can range from $0-50 \%$ and is observed in both obese and lean subjects (Bandini et al. 1990; Schoeller, 1990; Westerterp et al. 1991; Goris \& Westerterp, 1999; Goris et al. 2000). The under-reporting might be due to undereating (subjects consuming less while food recording) or to under-recording (failure to record in a food diary everything that is consumed). Earlier studies showed $16 \%$ under-reporting due to undereating in a group of lean women and $37 \%$ under-reporting in a group of obese men that could be divided into $26 \%$ undereating and $12 \%$ under-recording (Goris \& Westerterp, 1999; Goris et al. 2000). A second time of reporting food intake might change the proportions of undereating and under-recording. Previous studies that have measured food intake both before and after an intervention have not made the distinction between under-recording and undereating.
Westerterp et al. (1991) measured food intake (7 d dietary record) and energy expenditure (EE) (with doubly-labelled water) in sixteen non-obese men and women before and after a 40 week exercise intervention. Before the start of the intervention the difference between energy intake (EI) and EE was -5 (SD 28) \% and after the 40 weeks (thirteen subjects completed the training intervention) the difference had increased to -19 (SD 17) \%. The subjects perceived the reporting of food intake for the fourth time (subjects also reported food intake twice during the intervention) as a real burden (Westerterp et al. 1991).

Insight into the reporting of habitual food intake (undereating $v$. under-recording and selective underreporting) is needed to be able to detect changes in the food intake after an intervention. The aim of the present study was to measure differences in reporting behaviour between a first occasion of $7 \mathrm{~d}$ food recording and a second occasion of $7 \mathrm{~d}$ food recording in a group of men and women. Half of the group followed an exercise intervention of 12 weeks and the other half served as a control group. Under-reporting, undereating and under-recording (\%) 
were measured before and at the end of the 12 weeks. Reported EI was compared with EE as calculated from measured BMR and physical activity (PA) assessed with a tri-axial accelerometer for movement registration. Undereating was calculated from the change in body mass over the recording week and the under-recording was measured with the water balance technique as described recently (Goris \& Westerterp, 1999).

\section{Materials and methods}

\section{Subjects}

Twenty-six men and twenty-three women were recruited for a controlled exercise intervention study by advertisements in local newspapers. Forty-nine subjects participated in the baseline measurements of whom three dropped out of the study for personal reasons. From the forty-six subjects, twelve subjects had a missing PA registration in the first and/or second period. The results presented here are therefore from thirty-four subjects (nine men and ten women in the exercise group and eight men and seven women in the control group). They had a mean age of 61 (SD 5) years and a mean BMI $26.2\left(\right.$ SD 3.8) $\mathrm{kg} / \mathrm{m}^{2}$. Baseline characteristics were the same for both groups. The protocol was approved by the Medical Ethical Committee of the Maastricht University.

\section{Protocol}

The subjects were studied before the start of the exercise intervention (in the autumn) and during the final phase of the 12 week exercise intervention (in the winter). The measurements were performed in a 2 -week period. Food and water intake were measured over the second week simultaneously with the assessment of PA and water loss. BMR was measured in the first week. Body mass changes were determined over the first week and over the second week, the recording week, to control for changes in the diet (i.e. undereating) during the recording period (see Goris \& Westerterp, 1999). The water balance was also assessed over the recording week to measure the under-recording (i.e. the failure to record in a food diary everything that is consumed) (Goris \& Westerterp, 1999).

\section{Food and water intake}

Subjects recorded everything they consumed for $7 \mathrm{~d}$ in a structured food diary. They received instructions from a dietitian on how to fill in the diary (they did not have to weigh everything) and were asked not to change their dietary habits. The data on the food records were used to calculate intakes of total energy, protein, fat, carbohydrate and water with a computer program based on food tables (Becel nutrition program, 1988; Nederlandse Unilever bedrijven BV, Rotterdam, The Netherlands). Total water intake was calculated from reported food and water intakes and the calculated amount of metabolic water. The amount of metabolic water was estimated from protein, fat and carbohydrate intake derived from the $7 \mathrm{~d}$ food diary.
Oxidation water is $0.41 \mathrm{ml} / \mathrm{g}$ for protein, $1.07 \mathrm{ml} / \mathrm{g}$ for fat and $0.6 \mathrm{ml} / \mathrm{g}$ for carbohydrate (Fjeld et al. 1988).

\section{Energy expenditure and water loss}

EE was derived from BMR and PA as assessed with a triaxial accelerometer for movement registration. BMR was measured by means of a computerised open-circuit ventilated hood system, in the morning in a fasting state (subjects slept the night before at the university) while subjects were lying for $30 \mathrm{~min}$ in supine position. Gas analyses were performed by a paramagnetic $\mathrm{O}_{2}$ analyser (Servomex type 500A, Crowborough, Sussex, UK) and an infrared $\mathrm{CO}_{2}$ analyser (Servomex type 12-X1), similar to the analysis system described by Schoffelen et al. (1997). Weir's formulas were used for calculating BMR (Weir, 1949). PA was assessed with a tri-axial accelerometer for movement registration, the Tracmor (Philips Research, Eindhoven, The Netherlands). The Tracmor is a small device $(7 \times 2 \times 0.8 \mathrm{~cm}, 30 \mathrm{~g})$ and measures accelerations in the anteroposterior, mediolateral and vertical directions of the trunk. Subjects wore the Tracmor during waking hours and recorded the time they put on and off the Tracmor. Total counts per $\mathrm{d}$ were divided by the time subjects wore the Tracmor to get average counts/min (Bouten et al. 1996). Total EE was calculated with the formula: $\mathrm{EE}(\mathrm{MJ} / \mathrm{d})=$ $-1.259+1.55 \times \mathrm{BMR}+0.076 \times \mathrm{PA}$ (counts $/ \mathrm{min})\left(r^{2} 0.90\right.$, $P<0.0001$; SD $0.809 \mathrm{MJ} / \mathrm{d}$, derived from a validation against doubly-labelled water) (Goris et al. 2001).

Water loss was measured with ${ }^{2} \mathrm{H}$-labelled water $\left({ }^{2} \mathrm{H}_{2} \mathrm{O}\right.$, $70 \mathrm{~g}$ water with an enrichment of 5 atom $\%$ excess ${ }^{2} \mathrm{H}$ ). Subjects drank this dilution after voiding (baseline urine sample) the evening before the start of the 2 -week period. More urine samples were collected in the morning and evening of day 1 , evening of day 7 , morning of day 8 , evening of day 14 and morning of day $15 .{ }^{2} \mathrm{H}$ content was measured in urine samples with an isotope MS (Westerterp et al. 1996). Water loss was calculated over the second week from ${ }^{2} \mathrm{H}$ elimination with the equation of Fjeld et al. (1988), as described previously (Westerterp et al. 1992).

\section{Body mass}

Subjects were weighed (in underwear) in the morning before any food or beverage consumption and after voiding on day 1 , on a digital balance accurate to $0.01 \mathrm{~kg}$ (Sauter, Ebingen, Germany) and day 8 and 15, because of practical reasons, on a digital balance accurate to $0.1 \mathrm{~kg}$ (Seca, Almere, The Netherlands). Both balances were calibrated and gave the same results.

\section{Exercise intervention}

Subjects of the exercise group trained twice per week, for $1 \mathrm{~h}$, on non-consecutive days for 12 weeks. All training sessions were performed at a fitness centre and supervised by a fitness instructor. The intensity of the training programme was approximately $50 \%$ heart rate reserve. 


\section{Statistics}

Means and standard deviations were calculated. Body mass changes over the non-recording week and over the recording week were compared with paired $t$ tests (twosided) and the body-mass change over the recording week was also compared with zero in a one-group $t$ test (twosided). EI and EE, water intake and water loss were compared with each other in a paired $t$ test (two-sided). Non-parametric tests were used in case data were not normally distributed.

The under-reporting, under-recording and undereating were calculated for the exercise, control and total group separately and were calculated as follows:

$$
\text { under-reporting }(\%)=((\mathrm{EI}-\mathrm{EE}) / \mathrm{EE}) \times 100 \% \text {, }
$$

undereating $(\%)=(($ body mass change $\times 30 \mathrm{MJ} / 7 \mathrm{~d}) / \mathrm{EE})$

$$
\times 100 \%
$$

under-recording $(\%)=(($ water intake

$$
\text { - water loss)/water loss) } \times 100 \% \text {. }
$$

The different variables measured in period 1 and 2 were compared with paired $t$ test (two-sided) and/or simple regression analysis. Significance was set at $P<0 \cdot 05$. The STATVIEW program (1992-98; Statistical Analysis Systems Institute Inc., Cary, NC, USA) was used for the statistical analysis.

\section{Results}

Table 1 shows the mean results of reported EI, BMR, PA counts and calculated EE of period 1 and 2 for both the exercise and control group. No differences in EI and EE were found between the exercise and control group. The calculated \% under-reporting was also not significantly different between the two groups (Table 2). Fig. 1 shows the $\%$ under-reporting in period two plotted against the $\%$ under-reporting in period one for the total group (simple regression analysis $\left.r^{2} 0.73, P<0.0001\right)$. The degree of under-reporting remains rather constant within subjects.

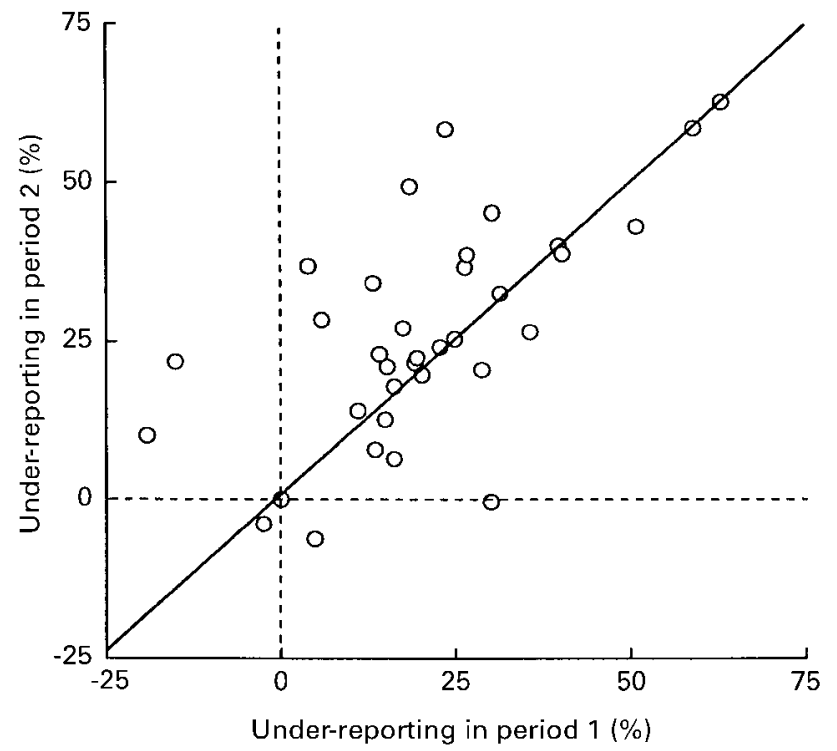

Fig. 1. Under-reporting (\%) during the second period plotted against under-reporting (\%) during the first period of $7 \mathrm{~d}$ food recording, with the calculated regression line: under-reporting in the second period $(\%)=0.98 \times$ under-reporting in the first period $(\%)+0.81(r 0.85$, $p<0.0001$ ). For details of subjects and procedures, see p. 630 .

Individual changes in reported EI were due to individual differences in the amount of under-reporting between period 1 and 2 (Fig. 2; simple regression analysis $r^{2} 0.77$, $P<0.0001)$. The body-mass change over the first recording week was not different from zero for the total group (one group $t$ test, $P=0 \cdot 16$ ) and also for the exercise (one sample sign test, $P=0.33$ ) and control group (one sample sign test, $P=0.30$ ) separately (Table 3 ) and there was no undereating in the first period. In the second period the body-mass change over the recording week was significantly different from zero for the total group (one group $t$ test, $P=0.03$ ) and from the body-mass change over the non-recording week in the second period of 0.23 (SD 0.64) $\mathrm{kg}$ (paired $t$ test, $P=0 \cdot 01$ ). The body-mass change over the second recording week for the exercise and control group were not significantly different from zero (one sample sign test; exercise group $P=0.08$, control group $P=0.18$ ). Undereating in the second period was 15.4 (SD 18.1) \% for

Table 1. Body mass (BM), BMI, reported energy intake (EI), BMR, physical activity (PA) and total calculated energy expenditure (EE) for two

\begin{tabular}{|c|c|c|c|c|c|c|c|c|c|c|c|c|}
\hline & \multicolumn{6}{|c|}{ Period 1} & \multicolumn{6}{|c|}{ Period 2} \\
\hline & \multicolumn{2}{|c|}{ Exercise } & \multicolumn{2}{|c|}{ Control } & \multicolumn{2}{|c|}{ Total } & \multicolumn{2}{|c|}{ Exercise } & \multicolumn{2}{|c|}{ Control } & \multicolumn{2}{|c|}{ Total } \\
\hline & Mean & SD & Mean & SD & Mean & SD & Mean & SD & Mean & SD & Mean & SD \\
\hline $\mathrm{BM}(\mathrm{kg})$ & 74.3 & 11.0 & 75.7 & $11 \cdot 8$ & 74.9 & $11 \cdot 2$ & 74.6 & $10 \cdot 8$ & $76 \cdot 7$ & 11.7 & 75.5 & $\overline{11.1}$ \\
\hline BMI $\left(\mathrm{kg} / \mathrm{m}^{2}\right)$ & $26 \cdot 1$ & 3.1 & $26 \cdot 3$ & $4 \cdot 6$ & $26 \cdot 2$ & 3.8 & $26 \cdot 2$ & 3.0 & $26 \cdot 6$ & 4.5 & $26 \cdot 4$ & 3.7 \\
\hline El $(M J / d)$ & $8 \cdot 0^{\star}$ & $2 \cdot 2$ & $9 \cdot 3^{*}$ & $2 \cdot 6$ & $8 \cdot 6^{\star}$ & 2.4 & $7 \cdot 5^{\star}$ & $2 \cdot 0$ & $8 \cdot 9^{\star}$ & $2 \cdot 1$ & $8 \cdot 1^{*}$ & $2 \cdot 2$ \\
\hline BMR (MJ/d) & 6.5 & $1 \cdot 1$ & 6.7 & $1 \cdot 2$ & $6 \cdot 6$ & $1 \cdot 1$ & 6.5 & $1 \cdot 0$ & 6.9† & $1 \cdot 1$ & $6 \cdot 7$ & $1 \cdot 0$ \\
\hline PA (counts/min) & $25 \cdot 3$ & $10 \cdot 6$ & $26 \cdot 7$ & 11.4 & 25.9 & $10 \cdot 8$ & $25 \cdot 1$ & 7.4 & $29 \cdot 6$ & $11 \cdot 2$ & $27 \cdot 1$ & $9 \cdot 4$ \\
\hline EE (MJ/d) & $10 \cdot 7$ & 1.9 & $11 \cdot 1$ & $1 \cdot 7$ & 10.9 & $1 \cdot 8$ & $10 \cdot 7$ & 1.6 & $11.7 \dagger$ & 1.9 & $11 \cdot 1$ & $1 \cdot 8$ \\
\hline
\end{tabular}
repeated measurements (period 1 and period 2) $\ddagger$

(Mean value and standard deviations for nineteen subjects in the exercise group and fifteen subjects in the control group)

Mean values were significantly different from $\mathrm{EE}:{ }^{*} P<0.05$

Mean value was significantly different from that in period $1: \dagger P<0.05$

¥ For details of subjects and procedures see p. 630 . EE was calculated from BMR and PA counts. There were 12 weeks between periods 1 and 2 . 
Table 2. The amount of under-reporting, under-recording and undereating for two repeated measurements (period 1 and period 2 ) $\ddagger$ (Mean values and standard deviations for nineteen subjects in the exercise group and fifteen subjects in the control group)

\begin{tabular}{|c|c|c|c|c|c|c|c|c|c|c|c|c|}
\hline & \multicolumn{6}{|c|}{ Period 1} & \multicolumn{6}{|c|}{ Period 2} \\
\hline & \multicolumn{2}{|c|}{ Exercise } & \multicolumn{2}{|c|}{ Control } & \multicolumn{2}{|c|}{ Total } & \multicolumn{2}{|c|}{ Exercise } & \multicolumn{2}{|c|}{ Control } & \multicolumn{2}{|c|}{ Total } \\
\hline & Mean & SD & Mean & $\overline{S D}$ & Mean & $\overline{S D}$ & Mean & $\overline{S D}$ & Mean & SD & Mean & SD \\
\hline Under-reporting (\%) & $25 \cdot 1$ & $15 \cdot 9$ & $16 \cdot 2$ & $18 \cdot 8$ & $21 \cdot 2$ & 17.5 & $29 \cdot 7^{\star}$ & $16 \cdot 4$ & $23 \cdot 4$ & 17.9 & $26 \cdot 9^{*}$ & $17 \cdot 1$ \\
\hline Under-recording (\%) & $23 \cdot 0$ & $12 \cdot 9$ & $17 \cdot 3$ & $10 \cdot 5$ & 20.5 & $12 \cdot 1$ & $18 \cdot 4 \dagger$ & $10 \cdot 2$ & 22.5 & $14 \cdot 6$ & $20 \cdot 2$ & $12 \cdot 3$ \\
\hline Undereating (\%) & - & & - & & - & & - & & - & & $15 \cdot 4$ & $18 \cdot 1$ \\
\hline
\end{tabular}

Mean value was significantly different from that in period $1\left({ }^{*} P<0.05\right)$.

Mean value was significantly different from under-reporting (paired sign test, $\dagger P=0.019$ )

$\ddagger$ For details of subjects and procedures, see p. 630. There were 12 weeks between periods 1 and 2 .

Table 3. The body mass change over the recording week $(\Delta \mathrm{BM})$, total water intake plus metabolic water (WI) and water loss (WO) for two repeated measurements (period 1 and period 2) $\ddagger$

(Mean values and standard deviations for nineteen subjects in the exercise group and fifteen subjects in the control group)

\begin{tabular}{|c|c|c|c|c|c|c|c|c|c|c|c|c|}
\hline & \multicolumn{6}{|c|}{ Period 1} & \multicolumn{6}{|c|}{ Period 2} \\
\hline & \multicolumn{2}{|c|}{ Exercise } & \multicolumn{2}{|c|}{ Control } & \multicolumn{2}{|c|}{ Total } & \multicolumn{2}{|c|}{ Exercise } & \multicolumn{2}{|c|}{ Control } & \multicolumn{2}{|c|}{ Total } \\
\hline & Mean & SD & Mean & SD & Mean & SD & Mean & SD & Mean & SD & Mean & SD \\
\hline$\Delta \mathrm{BM}(\mathrm{kg} /$ week $)$ & -0.37 & 0.71 & -0.01 & 0.82 & -0.20 & 0.77 & -0.26 & 0.64 & -0.23 & 0.69 & $-0.25 \dagger$ & 0.65 \\
\hline WI (litres/d) & $2 \cdot 3^{\star \star \star \star}$ & 0.8 & $2 \cdot 6^{\star \star \star \star}$ & 0.7 & $2 \cdot 4^{\star \star \star \star}$ & 0.7 & $2 \cdot 2^{\star \star \star \star}$ & 0.6 & $2 \cdot 2^{\star \star \star \star}$ & 0.5 & $2 \cdot 2^{\star \star \star \star}$ & 0.6 \\
\hline WO (litres/d) & $2 \cdot 9$ & 0.7 & 3.2 & 0.7 & 3.0 & 0.7 & $2 \cdot 7$ & 0.6 & 2.9 & 0.5 & $2 \cdot 8$ & 0.6 \\
\hline
\end{tabular}

Mean values were significantly different from WO (paired $t$ test, ${ }^{\star \star \star \star} P<0.0001$ ).

Mean value was significantly different from zero (one group $t$ test, $\dagger P=0.03$ ).

$\ddagger$ For details of subjects and procedures, see p. 630. There were 12 weeks between periods 1 and 2 .

the total group (Table 2). The body-mass change of -0.62 (SD 1.9) $\mathrm{kg}$ between period 1 and 2 was not significantly different from zero (one group $t$ test, $P=0.72$ ).

The results of total water intake (reported + metabolic) and water loss for the exercise, control and total group are

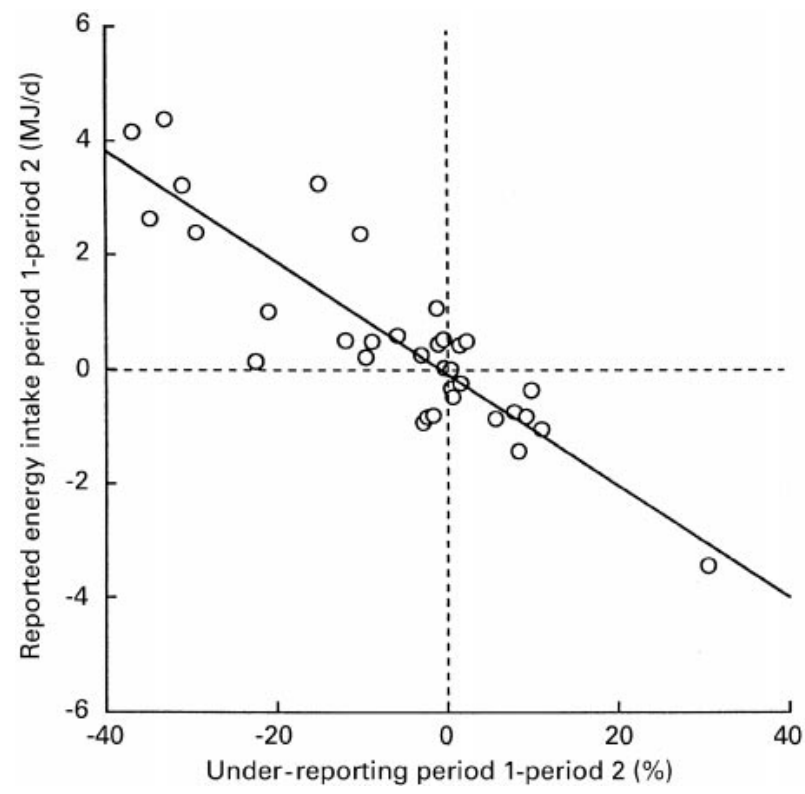

Fig. 2. The difference in reported energy intake between period 1 and 2 plotted against the difference of the under-reporting (\%) between period 1 and 2 , with the calculated regression line: difference in energy intake $=-0.1 \times$ difference in under-reporting (\%) -0.09 ( $r 0.88, P<0.0001)$. For details of subjects and procedures, see p. 630 . described in Table 3. Total water intake was significantly lower (paired $t$ tests, $P<0.0001$ for all groups) than measured water loss indicating under-recording (Table 2). The $\%$ under-reporting and under-recording in period $1 \mathrm{did}$ not differ from each other in a paired $t$ test for the total group $(P=0.82)$ and in a paired sign test for the exercise $(P=0.36)$ and for the control group $(P=0.61)$ (Table 2$)$. The sum of the $\%$ undereating and under-recording for the total group in period two was also not significantly different from the total $\%$ under-reporting in period two $(P=0 \cdot 06$, exclusion of one outlier $P=0 \cdot 11)$. The outlier mentioned was a subject from the exercise group who lost $1.8 \mathrm{~kg}$ over the second recording week. The \% underreporting and under-recording in period 2 were significantly different from each other in the exercise group (paired sign test, $P=0 \cdot 02$ ), but not in the control group (paired sign test, $P=0.999$ ). The difference between under-reporting and under-recording in period 2 for the exercise group was probably due to a small amount of undereating which did not reach significance (body-mass change over the recording week for the exercise groups was not different from zero, $P=0.08$ ).

The reported \% energy from fat, carbohydrate and protein in period 1 were respectively $36 \cdot 1$ (SD $4 \cdot 5)$, $43 \cdot 2$ (SD 6.8) and 15.5 (SD 3.1) and were not different from the reported $\%$ energy from fat, carbohydrate and protein in period 2 of 36.3 (SD 5.6), 42.2 (SD 6.0) and 15.9 (SD 3.0) respectively (paired $t$ tests, $P>0 \cdot 05$ ). Absolute intakes of protein and fat were not significantly different between period 1 and 2 . Only the carbohydrate intake was lower in period 2 compared with period 1 (paired $t$ test, $P=0.02$ ). In the first period the $\%$ energy from fat, carbohydrate and protein were not related in simple regression analysis 


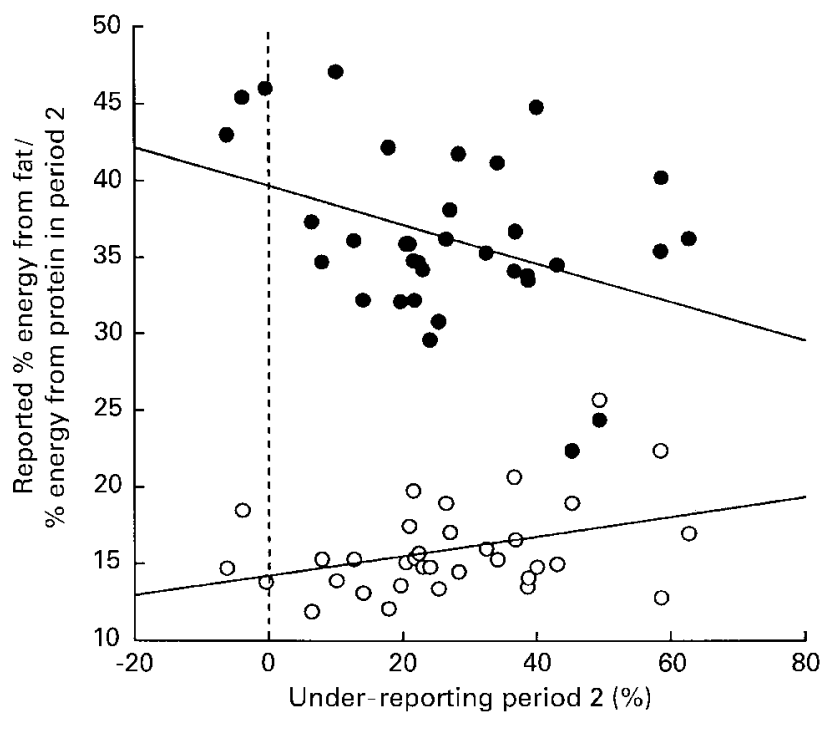

Fig. 3. Reported \% energy from fat and protein plotted against under-reporting (\%) for the second period with the calculated regression lines: $\%$ energy from fat $=-0.13 \times$ under-reporting $(\%)+$ $40(r-0.39, P=0.02)$ and $\%$ energy from protein $=0.06 \times$ under-reporting $(\%)+14(r 0.37, P=0.02)$. $\bullet, \%$ energy from fat; $\mathrm{O}, \%$ energy from protein. For details of subjects and procedures, see p. 630 .

( $P>0 \cdot 05$, data not reported) to the total $\%$ underreporting, thus there was no indication for selective under-reporting of macronutrients. However, in the second period the $\%$ energy from fat and from protein were significantly related to the \% under-reporting (Fig. 3, simple regression analysis both $P=0 \cdot 02$, not influenced by exercise intervention). Table 4 shows the results of simple regression analysis of reported EI at the different meals related to the $\%$ under-reporting for periods 1 and 2 . The reported EI at the different meals were all related to the $\%$ under-reporting, thus there was no selective underreporting of food intake at specific meals.

\section{Discussion}

The results of the repeated measurement of food intake with a 12-week interval in a group of elderly men and women showed an increase of about $6 \%$ in the total

Table 4. Simple regression analysis of reported energy intakes at different meals $(y)$ and the percentage under-reporting $(x)$ in thirtyfour subjects for two repeated measurements (period 1 and 2$)^{\star}$

\begin{tabular}{lrrrrr}
\hline & \multicolumn{2}{c}{ Period 1 } & & \multicolumn{2}{c}{ Period 2 } \\
\cline { 2 - 3 } \cline { 5 - 6 }$y$ & $r$ & & & $r$ & $P$ \\
\hline Breakfast & 0.38 & 0.0282 & & 0.40 & 0.019 \\
Morning snack & 0.33 & 0.0608 & & 0.32 & 0.064 \\
Lunch & 0.52 & 0.0018 & & 0.48 & 0.004 \\
Afternoon snack & 0.65 & $<0.0001$ & & 0.59 & 0.0002 \\
Dinner & 0.53 & 0.0013 & & 0.62 & $<0.0001$ \\
Evening snack & 0.46 & 0.0067 & & 0.19 & 0.289 \\
\hline
\end{tabular}

* For details of subjects and procedures, see p. 630. There were 12 weeks between periods 1 and 2 . amount of under-reporting. The \% under-recording remained the same, but during the second period subjects ate less than usual. Besides the increase in the \% underreporting in the second period, subjects also selectively under-reported their fat intake and overreported their protein intake. Individual differences in reported EI were explained by differences in the amount of under-reporting between periods 1 and 2 . Thus, the assessment of food intake the second time caused a higher quantitative and a qualitative under-reporting of food intake.

Whether subjects had an exercise intervention or not did not seem to influence the food reporting here. This might have been different if instead of an exercise intervention, a nutrition intervention was performed, as was done in a study of Kristal et al. (1998). They showed half of their subjects a videotape with information on the consequences of eating a high-fat diet and the other half a placebo videotape. Subjects received pre-intervention and post-intervention assessment or only post-intervention assessment of their diet. The reported fat intake significantly decreased $(P<0.05)$ in the subjects who watched the intervention videotape compared with the control subjects. The effect of a nutrition intervention influenced the reporting of food intake, while the real food intake was not changed and thus one might say that the nutrition intervention failed (Kristal et al. 1998). This effect was also reported by Johansson et al. (1992), where subjects had to change from a mixed diet to a lactovegetarian diet. The reported fibre intake at 3, 6 and 12 months was compared with biological markers for fibre intake (i.e. total faecal weight, water content in faeces and excretion of short-chain fatty acids). The validity of the food intake was the same before the dietary shift and at 3 months and was lowest at 12 months. The compliance to the new diet was decreased although subjects did not report this (Johansson et al. 1992).

In the current study, the degree of under-reporting between the two periods was rather constant within subjects. Subjects who reported their food intake the first time accurately did this also the second time and vice versa. The $\%$ under-reporting was not related to subject characteristics such as BMI or age (data not reported) as was found in some other studies (Westerterp et al. 1991; Johnson et al. 1994).

In the second period a selective under-reporting of fat and an over-reporting of protein intake was measured. A selective under-reporting of fat was reported previously in obese men (Goris et al. 2000) and also in two other studies with older men and women (Schaefer et al. 2000; Tomoyasu et al. 2000). We observed no selective omission of foods at specific meals, as was found in a study with obese men who selectively under-reported their food intake at lunch, dinner and during the evening (Goris et al. 2000). Subjects changed their diet during the second period by eating less ( $15 \%$ undereating). Food recording for $7 \mathrm{~d}$ is often perceived as quite a burden and this might result in subjects eating less and differently (Goris et al. 2000; Goris \& Westerterp, 2000). A second time of food recording might increase this behaviour even more (Westerterp et al. 1991). The reason for selective under-reporting of fat and over-reporting of protein during the second period remains unclear. Subjects did not receive any information on 
nutrition or a healthy diet and the exercise did also not influence the results, thus the selective under- and overreporting is not the result of a specific intervention.

The mean body mass, total EE and EI in period 1 and 2 did not differ significantly between both periods. Individual changes in total reported food intake were due to changes in the amount of under-reporting. Total reported food intake between both periods thus remained the same. However, the food choice of subjects might have been different between both periods, because period 1 was in the autumn and period 2 in the winter. The \% energy from fat, carbohydrate and protein did not differ between both periods, but during the second period subjects selectively under-reported fat and over-reported their protein intake. A seasonal effect of food choice was probably present in the current study. The changed errors in the food reporting covered the changes in the habitual food intake between the two measurements. The effect of nutrition, exercise or other interventions on food intake might thus not be discovered. A biomarker for reported food intake must be included in studies of the effect of an intervention on food intake.

In the second period the sum of the undereating $(15 \%)$ and the under-recording (18\%) was higher than the total amount of under-reporting (27\%), although the difference was not significant. For the calculation of the $\%$ undereating, the energy content of $1 \mathrm{~kg}$ body mass was assumed to be $30 \mathrm{MJ}$ (75\% fat mass, $25 \%$ fat-free mass with $73 \%$ water) (Westerterp et al. 1995; Goris \& Westerterp, 1999). The used mass ratio for storage or mobilisation of energy between fat and fat-free mass might differ on the individual level and errors in the calculation of undereating are the result. Besides an error in the calculation of the amount of undereating, a small error in the calculation of underreporting might also be present. The amount of underreporting is calculated from EE as derived from BMR and PA. The formula for the calculation of EE had a residual SD $0.809 \mathrm{MJ} / \mathrm{d}$ and small errors in the estimation of EE might be present. However, in a former study the combination of BMR and PA as assessed with a tri-axial accelerometer was found to be a good validation method for reported EI (Goris et al. 2001).

The results presented here are for a group of elderly men and women and more research is needed to find out whether these results also apply for younger age groups.

In summary, a second time of food reporting after 12 weeks caused a higher total under-reporting due to subjects consuming less than habitual and a selective underreporting of fat and over-reporting of protein intake.

\section{References}

Bandini LG, Schoeller DA, Cyr HN \& Dietz WH (1990) Validity of reported energy intake in obese and nonobese adolescents. American Journal of Clinical Nutrition 52, 421-425.

Bouten C, Verboeket-van de Venne W, Westerterp K, Verduin M \& Janssen J (1996) Daily physical activity assessment: comparison between movement registration and doubly labeled water. Journal of Applied Physiology 81, 1019-1026.

Fjeld CR, Brown KH \& Schoeller DA (1988) Validation of the deuterium oxide method for measuring average daily milk intake in infants. American Journal of Clinical Nutrition 48, 671-679.

Goris AHC, Meijer EP, Kester A \& Westerterp KR (2001) The use of a tri-axial accelerometer for the validity of reported food intake. American Journal of Clinical Nutrition (In the Press).

Goris AHC \& Westerterp KR (1999) Underreporting of habitual food explained by undereating in motivated lean women. Journal of Nutrition 129, 878-882.

Goris AHC \& Westerterp KR (2000) Improved reporting of habitual food intake after confrontation with earlier results on food reporting. British Journal of Nutrition 83, 363-369.

Goris AHC, Westerterp-Plantenga MS \& Westerterp KR (2000) Undereating and underrecording of habitual food intake in obese men; selective underreporting of fat intake. American Journal of Clinical Nutrition 71, 130-134.

Johansson G, Callmer E \& Gustafsson J-A (1992) Validity of repeated dietary measurements in a dietary intervention study. European Journal of Clinical Nutrition 46, 717-728.

Johnson RK, Goran MI \& Poehlman ET (1994) Correlates of over- and underreporting of energy intake in healthy older men and women. American Journal of Clinical Nutrition 59, 12861290.

Kristal AR, Andrilla HA, Koepsell TD, Diehr PH \& Cheadle A (1998) Dietary assessment instruments are susceptible to intervention-associated response set bias. Journal of the American Dietetic Association 98, 40-43.

Schaefer E, Augustin J, Schaefer M, Rasmussen H, Ordovas J \& Dallal G (2000) Lack of efficacy of a food-frequency questionnaire in assessing dietary macronutrient intakes in subjects consuming diets of known composition. American Journal of Clinical Nutrition 71, 746-751.

Schoeller DA (1990) How accurate is self-reported dietary energy intake? Nutrition Reviews 48, 373-379.

Schoffelen PFM, Westerterp KR, Saris WHM \& Hoor ten F (1997) A dual-respiration chamber system with automated calibration. Journal of Applied Physiology 83, 2064-2072.

Tomoyasu N, Toth M \& Poehlman E (2000) Misreporting of total energy intake in older African Americans. International Journal of Obesity 24, 20-26.

Weir JB (1949) New methods for calculating metabolic rate with special reference to protein metabolism. Journal of Physiology 109, 1-9.

Westerterp K, Verboeket-van de Venne W, Meijer G \& Hoor ten F (1991) Self-reported intake as a measure for energy intake. A validation against doubly labelled water. Obesity Europe 91, $17-22$.

Westerterp KR, Donkers JH, Fredrix EW \& Boekhoudt P (1995) Energy intake, physical activity and body weight: a simulation model. British Journal of Nutrition 73, 337-347.

Westerterp KR, Kayser B, Brouns F, Herry JP \& Saris WH (1992) Energy expenditure climbing Mt. Everest. Journal of Applied Physiology 73, 1815-1819.

Westerterp KR, Robach P, Wouters L \& Richalet JP (1996) Water balance and acute mountain sickness before and after arrival at high altitude of 4,350 m. Journal of Applied Physiology 80, 1968-1972. 